\title{
Hvor går Afghanistan hen?
}

\section{Kai Eide}

\section{De gamle krigsherrers tid ikke er forbi. Valget av Fahim som første vicepræsident understregede, at de fortsat vil forgifte det politiske liv i landet - og de står stærkere i dag end for to år siden.}

Nedenstående er et kapitel af den norske diplomat Kai Eides seneste bogudgivelse 'Høyt Spill om Afghanistan' (Se bognoter).

Kai Eide siger til spørgsmålet fra Udenrigs, om vi må se Afghanistan som en fejlslagen stat: "Jeg vil ikke gå så langt. Afghanistan var jo et land uden fungerende institutioner. Hvis man kan få en dialog $i$ gang med Taleban, få ivarksat opbygningen af et fungerende retssystem og fä gang $i$ den фkonomiske udvikling, så tror jeg, at en fungerende afghansk stat kan skabes, men det er nationsopbygning, som skal til. En forudsatning er imidlertid, at den afghanske befolkning ser en vilje fra det internationale samfund til at andre den nuverende alt for militariserede kurs".

Jeg gjør ikke krav på å forstå Afghanistan. Mine muligheter til å bevege meg fritt og snakke med folk var begrenset - både av sikkerhetsgrunner og fordi jeg ble fanget inn i det poli- tiske spillet i Kabul. Ofte ville jeg gjerne gå ut av bilen under kjøreturer utenfor den mest sikrede sonen av Kabul og tilbringe tid på markedene, hvor vanlig folk ferdes. Men dersom jeg hadde gjort det ville jeg ha vært omgitt av så mange sikkerhetsfolk at normale samtaler ville ha vært håpløst.

For internasjonale besøkende blir bildet av Afghanistan ofte formet av møtet med den befestede delen av Kabul, samtaler med engelsktalende og vestlig orienterte ledere og optimistiske orienteringer gitt av internasjonale representanter. Da er det ikke Afghanistan man møter. Selv i andre deler av Kabul fortoner livet seg ganske annerledes enn i de kvartalene hvor høye betongmurer har vokst opp på hver side av veien og hvor veisperringer står med noen hundre meters mellomrom.

Forskjellen mellom de storbyene vi oftest besøker og landsbygda er 
dramatisk. Den britiske forsvarsministeren fornærmet nok en del afghanere når han under sitt første besøk i Afghanistan snakket om et land som befinner seg i det trettende århundre. Men virkeligheten er at man på kort tid kan reise flere århundrer tilbake i tid - fra Kabuls endeløse bilkøer og veisperringer til områder og landsbyer hvor esler fortsatt er det viktigste fremkomstmiddel, hvor analfabetismen er nesten total og landbruket drives med foreldete metoder. Selv afghanere i fremskutte posisjoner, men med vestlig bakgrunn, blir iblant overrasket. Etter at president Karzai hadde vært på besøk ute i en av provinsene, kunne en person i hans eget følge si til meg: "Jeg har tilbrakt en dag i det virkelige Afghanistan." I slike områder tikker ikke bare klokkene i en annen takt enn i de hektiske vestlige land hvor strategiene formes. Det virker som om de står stille. Vi makter ikke å fange det afghanske samfunnets puls på en tilfredsstillende måte.

\section{Uddannelse for alle}

Ofte forstår vi heller ikke hva religionen betyr for det overveldende flertall av afghanere. Under en stor markering av "Education for all"kampanjen i 2008 skulle presidenten og jeg selv tale i Kabul. Der satt festkledte unger på benkeradene, sammen med foreldre og lærere. Jeg festet meg ved en gruppe små- jenter på første rad. Karzai var forsinket, så jeg gikk bort til dem med hele mediakorpset i hælene. På huk foran tre av dem spurte jeg hvilke fag de likte og mislikte; regning var ikke populært, men historie likte de alle tre. Da jeg ba dem forklare hvorfor, svarte de unisont: For da lærer vi om profetens liv.

Senere ble jeg kjent med den unge jenta i begynnelsen av tenårene som jeg tidligere har nevnt. Jenta utstrålte talent og energi. Hun ville opp og frem i verden. Jeg forsøkte å inspirere henne til å bli bedre i engelsk og forklarte at uten engelsk ville hun ikke kunne studere og forstå andre land. Hun gjorde raske fremskritt og etter en tid var tolken overflødig og samtalen fløt lettere. Jeg var både glad og imponert. En dag ga hun meg det første arbeidet hun hadde skrevet til meg på engelsk. Den handlet om profetens liv. Jeg ble overrasket. Jeg hadde forventet en fortelling om hennes liv og om hennes forhåpninger.

Disse jentene kom alle fra Kabul, fra selve hovedstaden, hvor innbyggerne mer enn noe annet sted er utsatt for impulser utenfra. Hvis dette var deres forhold til religionen, hvordan var det da på landsbygda? For meg ble de to små hendelsene en illustrasjon på noe jeg skulle komme til å oppleve mange ganger; vi har i Vesten - selv med betydelige muslimske minoritetsgrupper $\mathrm{i}$ våre egne land - store problemer med å 
forstå religionens rolle. Det er få ting som kan skape opptøyer slik som et rykte om at utenlandske soldater har skjendet Koranen. Og det er få ting som kan sette sinnene i kok på samme måte som karikaturtegninger av profeten. Begge deler rammer sentralt i deres eget selvbilde og oppfatning av livet og samfunnet - av deres identitet. Her er det ikke snakk om muslimsk ekstremisme, slik det iblant fremstilles i vestlige land.

Jeg har alltid ment at vi må verne om ytringsfriheten. Men det er ikke alle ytringer som er kloke og nødvendige. Vi reagerer med sjokk når flagget vårt brennes av rasende folkemengder. Men det norske flaggets betydning selv for den mest patriotiske nordmann, har på langt nær den samme betydning i våre egne liv som krenkelser av islam har for den jevne afghaner.

\section{Forståelse kræver tid}

Verden er blitt liten når det gjelder kommunikasjon. Hva man sier i den minste lokalavis kan på noen minutter bli en mediasak av global karakter. Nyheter formidles på sekunder. Men å formidle forståelse krever tid. Faren ligger i at vi i stedet for å søke gjensidig forståelse skremmes av hverandres reaksjoner. Der ligger kimen til kollisjonen mellom sivilisasjoner og religioner. Og evnen til å forstå er nøkkelen til å kunne bistå Afghanistan med å få slutt på sin egen konflikt. Jeg mener ikke dermed at vi skal akseptere undertrykking og overgrep, enten disse er uttrykk for århundregamle tradisjoner eller for nye radikale tolkninger av islam. Men forståelse utgjør en forutsetning for å kunne medvirke til forandring.

Stadig oftere konfronteres vi med det grunnleggende spørsmålet: Hvorfor er vi fortsatt i Afghanistan? Er det for å bekjempe al-Qaeda, krigen mot terror, eller er det for å skape et mer moderne og fungerende samfunn, det vil si statsbygging? Noen har formulert det enda mer retorisk; er vi der for å forhindre nye terrorangrep mot vestlige mål eller for å sørge for at afghanske jenter skal kunne gå på skolen? Spørsmålet gjenspeiler behovet for å finne et realistisk ambisjonsnivå for vårt nærvær og for å kunne forlate landet med en følelse av at oppdraget er utført. Det er ikke mulig å gi et enkelt svar. Men la oss ta utgangspunkt i et ambisjonsnivå som ligger nærmere den beskjedne enden av spekteret enn den ambisiøse: Vårt mål er å forhindre at al-Qaeda og ekstremistiske bevegelser igjen får fotfeste i landet med fare for at de kan spre seg i regionen og utgjøre en fare for internasjonal sikkerhet. Hva er påkrevet for å gi Afghanistan evne og styrke til å beskytte seg selv mot en slik utvikling? La meg kort nevne fire elementer: For det første en afghansk politisk elite preget av overordnede 
nasjonale mål og ikke av lokal tilhørighet og egne interesser. Med politisk elite mener jeg ikke bare regjeringen, selv om det er viktig nok. Eliten omfatter mennesker med avgjørende innflytelse fra ulike deler av landet. I den nåværende situasjonen betyr det også gamle krigsherrer og sterke menn fra fortidens stridigheter, som fortsatt har makt til å splitte og makt til å samle. De vil fortsatt ha egne interesser og lokal tilhørighet som vil styre dem. Men de må finne frem til en tilstrekkelig grad av fellesskap og visjon for landets fremtid. Det er minst like viktig for det internasjonale samfunnet at afghanerne blir enige seg imellom som at de er enige med oss.

\section{Enighed om forsoning}

For det andre må det skapes enighet omkring en forsoningspolitikk over for opprørsbevegelsen. Det må være et av de overordnede nasjonale målene. Den store fredsjirgaen i begynnelsen av juni 2010 skapte ingen tilstrekkelig konsensus om forsoning. En bredere og mer tidkrevende prosess må til for å skape en slik konsensus. Det internasjonale samfunnet må vise at det står utvetydig bak en forsoningspolitikk og skyve afghanerne i retning av enighet snarere enn å opptre som tvilende partnere. Jo lenger vi nøler jo mer vil svakhetstegnene bli fremherskende. Vi trenger en forsoningspoli- tikk som er basert på at vi har tiltro til oss selv og som kan gi afghanerne tiltro til fremtiden.

For det tredje må vi styrke innsatsen for å bygge sivile afghanske institusjoner som befolkningen kan stole på. Det vil kreve store beløp. Men det er småpenger sammenlignet med det som går med for å bygge opp afghanske sikkerhetsstyrker som ikke på mange år kan ta ansvaret for befolkningens sikkerhet. Hver dag mister afghanske og internasjonale soldater sine liv på grunn av mangelen på sivile institusjoner befolkningen kan ha tiltro til. Hver dag rekrutteres en Taliban-kjemper av samme grunn.

For det fjerde må internasjonal bistand dirigeres over i prosjekter som kan generere produksjon, sysselsetting og inntekter til staten. Bare på den måten kan afghanerne selv gjenvinne optimisme og gradvis skape varig sosial og økonomisk vekst. Uten institusjoner som har befolkningens tiltro og uten utsikter til bedre økonomiske og sosiale kår vil befolkningens motstandskraft mot ekstremistiske bevegelser forbli svak.

Er det realistisk å forvente at vi kan enes om en slik dagsorden og at vi kan iverksette den? Det er et åpent spørsmål. Hvert enkelt punkt vil kreve en kraftanstrengelse både fra afghanere og det internasjonale samfunnet. Inntil i dag har vi ikke vist tilstrekkelig evne til å iverksette disse elementene, men de er alle en del av den agendaen som ble vedtatt 
under Kabul-konferansen den 20. juli 2010. Alternativet er den militariserte strategien, som i dag dominerer og som ganske sikkert vil mislykkes.

Når spørsmålet om hvor lenge 'vi' må forbli i Afghanistan, er det også viktig å definere hvem 'vi' er. FN og dets særorganisasjoner må forbli i svært mange år. Sammen med frivillige organisasjoner vil de være de siste til å forlate landet. Derfor er det så farlig å betrakte FN og ISAF som deler av samme operasjon. FNs integritet må bevares uforstyrret av de kontroverser som følger med militære styrker, slik at et langsiktig nærvær kan hilses velkommen av afghanerne.

Jeg skulle ønske at de gamle krigsherrene og maktpolitikerne kunne forsvinne fra arenaen og gi plass til et tilstrekkelig antall reformpolitikere. Valget av Fahim som 1. visepresident var et dårlig tegn. Det var mer enn et valg av en mann. Det var et valg som markerte noe mer; nemlig at de gamle krigsherrenes tid ikke er forbi og at de fortsatt vil forgifte det politiske livet i landet. I dag står de sterkere enn for to år siden.

Under en samtale med en særdeles klok politiker - selv regjeringsmedlem i 2008 - fortalte han om erfaringene fra de første årene etter Talibans fall. Under jirgaene i 2002 og 2003 hadde han følt seg mismodig når han så hvordan krigsherrene og de gamle maktfigurene fortsatt satt der prominent plassert, sanksjonert av det internasjonale samfunnet. Han hadde tenkt at det ikke ville drøye lenge før disse menneskene ville være skjøvet til side og marginalisert.

Det internasjonale samfunnet ville ikke kunne tolerere deres fortsatte tilstedeværelse, både fordi det stred mot grunnleggende menneskerettigheter og fordi giverne ikke ville kunne akseptere å bruke så store ressurser hvis ikke landet selv fant frem til en reformkurs.

\section{Ung befolkning}

Nå mange år senere følte han at det var reformpolitikerne som var marginalisert. Landet ble fortsatt styrt av de som hadde ødelagt det og som hadde banet vei for Talibans fremvekst. Det ble styrt av mennesker med kortsiktige vinningsinteresser, rett foran øynene på den afghanske befolkningen. Afghanistan er et land med en svært ung befolkning, sa han. Dersom den unge generasjonen ser at korrupsjon gir gevinster og er ustraffet, hva slags verdier vil de da velge for sin egen virksomhet? Og dersom de mangler forhåpninger om et bedre liv på lengre sikt basert på lov og orden, hvordan kan vi da forhindre at de søker kortsiktige gevinster utenfor loven?

Jeg tror han har rett. Men vi mistet en anledning og vi har mistet tid. Etter valget den 18. september finnes det i Underhuset i landets lov- 
givende forsamling fortsatt mange kjente lovbrytere. De vil bli sittende der i nye fem år. Samtidig haster det med å finne løsninger på landets grunnleggende problemer. Det internasjonale samfunnet må gjøre det klart at også de som en gang rev landet i stykker nå må medvirke til at det bringes sammen.

I dag slites landet mellom motstridende krefter: På den ene siden de konservative og tilbakeskuende maktmenneskene jeg har omtalt og århundrer gamle tradisjoner. På den andre siden en moderniseringsprosess vi ofte ikke legger like mye merke til. Den største interessen for demokratiske prosesser finner vi blant den unge generasjonen i bysamfunnene. Mediarevolusjonen i Afghanistan skaper gradvis en ster- kere debatt blant afghanere om overgrep og om korrupsjon. Og den vil bringe impulser utenfra, som etter hvert også vil kunne prege det afghanske samfunnet utenfor de største byene.

Jeg har tro på denne moderniseringsprosessen og på at den etter hvert vil vinne frem. Men det vil kreve tid. Og det vil kreve vilje fra det internasjonale samfunnet til å styrke de reformkreftene som finnes i landet og la dem få fastlegge kursen i Kabul og ikke i Vesten.

Kai Eide, norsk topdiplomat og leder af FN's mission i Afghanistan, Unama, fra marts 2008 til marts 2010. Havde FNposter på Balkan, bl.a. om Kosovas status og i Bosnien 1997-98. 